Sports Education Study Program, University of Ma'arif Nahdlatul Ulama Kebumen

\title{
Physical Education Textbook Study: Techniques and Forms of Assessment of Knowledge and Skills of Middle School Students in Indonesia
}

\author{
Dani Sulistiantoro a , Feri Budi Setyawan ${ }^{\mathrm{b}}$ \\ ${ }^{a}$ STIE Wilwatikta, Surabaya, Indonesia \\ ${ }^{b}$ S1-PGSD Study Program, Faculty of Teacher Training and Education, Universitas Ahmad \\ Dahlan, Indonesia \\ danisulistiantoro@gmail.com ${ }^{a}$, feri.setyawan@pgsd.uad.ac.id ${ }^{b}$
}

\begin{abstract}
This research aims to find out the form and technique of assessment on aspects of knowledge and skills in the textbooks of students of physical education sports and health (PJOK) class VIII Curriculum 2013. The instruments in this study are researchers themselves who are equipped with a set of theories and data cards that contain techniques and forms of assessment of aspects of knowledge and skills. The instrument is validated by validation of content or content by experts or expert judgement in this case done by experts. Data collection technique with a record reading technique. Data analysis techniques use Miles and Huberman's interactive model analysis techniques. This research is qualitative descriptive research. The data source in this study is the textbook of students of PJOK Class VIII Curriculum 2013. Results in this study show that not entire forms and assessment techniques on aspects of knowledge and skills exist in every chapter in the PJOK Class VIII curriculum textbook 2013. In the aspect of knowledge only uses assessment techniques in the form of multiple choices, descriptions and assignments. Assessment techniques such as right wrong, matchmaking, stuffing and Q\&A have not been applied in the textbook of PJOK students curriculum class 2013. For the skill aspect only in the form of practices and products only. Project and portfolio assessment techniques have not been applied in the PJOK Class VIII Curriculum textbook 2013. After the review of the textbook PJOK Class VIII Curriculum 2013, hopefully there will be revisions in the assessment in the latest version of the 2013 Curriculum PJOK textbook that covers all variations in assessment forms and techniques in aspects of knowledge and skills. This research contributes to the importance of subsequent research on the development of variation in forms and complete assessment techniques including aspects of attitudes in PJOK.
\end{abstract}

Keywords: assessment, knowledge, skill, PJOK

\begin{abstract}
Abstrak
Penelitian ini bertujuan untuk mengetahui bentuk dan teknik penilaian pada aspek pengetahuan dan keterampilan dalam buku teks siswa pendidikan jasmani olahraga dan kesehatan (PJOK) kelas VIII Kurikulum 2013. Instrumen dalam penelitian ini adalah peneliti sendiri yang dibekali dengan seperangkat teori dan kartu data yang memuat teknik dan bentuk penilaian aspek pengetahuan dan keterampilan. Instrumen tersebut divalidasi dengan validasi konten atau isi oleh pakar atau expert judgement yang dalam hal ini dilakukan oleh ahli. Teknik pengumpulan data dengan teknik baca catat. Teknik analisis data menggunakan teknik analisis interactive model Miles dan Huberman.Penelitian ini merupakan penelitian deskriptif
\end{abstract}


kualitatif. Sumber data dalam penelitian ini adalah buku teks siswa PJOK Kelas VIII Kurikulum 2013. Hasil dalam penelitian ini menunjukkan bahwa belum seluruhnya bentuk dan teknik penilaian pada aspek pengetahuan dan keterampilan ada pada setiap bab dalam buku teks PJOK Kelas VIII Kurikulum 2013. Dalam aspek pengetahuan hanya menggunakan teknik penilaian yang berupa pilihan ganda, uraian dan penugasan. Teknik penilaian seperti benar salah, menjodohkan, isian dan tanya jawab belum di aplikasikan pada dalam buku teks siswa PJOK kelas Kurikulum 2013. Hasil dalam penelitian ini menunjukkan bahwa tidak seluruh bentuk dan teknik penilaian pada aspek pengetahuan dan keterampilan ada pada setiap bab dalam buku teks PJOK Kelas VIII Kurikulum 2013. Pada aspek pengetahuan hanya menggunakan teknik penilaian berupa pilihan ganda, uraian dan tugas. Teknik penilaian seperti benar salah, menjodohkan, isian dan tanya jawab belum diterapkan dalam buku ajar siswa PJOK Kurikulum 2013. Untuk aspek keterampilan hanya berupa praktik dan produk saja. Teknik penilaian proyek dan portofolio belum diterapkan pada buku teks PJOK Kelas VIII Kurikulum 2013. Setelah dilakukan review terhadap buku teks PJOK Kelas VIII Kurikulum 2013, diharapkan ada revisi penilaian di versi terbaru buku teks PJOK Kurikulum 2013 yang meliputi segala variasi bentuk dan teknik penilaian dalam aspek pengetahuan dan keterampilan. Penelitian ini memberikan kontribusi terhadap pentingnya penelitian selanjutnya tentang pengembangan variasi bentuk dan teknik penilaian yang lengkap termasuk aspek sikap dalam PJOK.

Kata Kunci: penilaian, pengetahuan, keterampilan, PJOK

\section{Introduction}

Textbooks or more commonly known as package books are often handbooks for teachers and students are books that are used as a means of learning in schools to support the teaching and learning process (Burhaein, 2017; Irawan \& Limanto, 2021). The function of textbooks is not only in the form of lessons, but textbooks can also develop character in learners (Mumpuni, 2018; Sutopo \& Misno, 2021). Mandatory reference for use of elementary and secondary education units or colleges that contain teaching materials that are most often used among all other teaching materials (Burhaein, 2020; Simamora, 2019). Textbooks are used by teachers and learners as a mandatory reference in the learning process. Textbooks are made with the aim to stimulate students or learners in thinking at a certain level of education with a particular field of study (Azizah \& Sudarto, 2021; Metzler, 2017). This textbook is written by experts in each field which contains everything from the learning process to the assessment process.

Assessment is a systematic and continuous process or activity to collect information about the process and learning outcomes of learners in order to make decisions based on criteria and considerations that have been determined (Arifin, 2012; Widiyono \& Mudiono, 2021). Assessment is the process of collecting and processing information to measure the achievement of learners' learning outcomes. Assessment is one of the important components in the implementation of education, with the quality of good assessment then we will know the quality of the learning process that we have done (Azizah \& Sudarto, 2021; Kemendikbud RI, 2016).

A good scoring system will encourage educators to determine good teaching strategies in motivating learners to learn better. Based on this, the assessment tools in the textbooks of students of PJOK class VIII curriculum 2013 must be carried out in accordance with the actual techniques and forms of assessment (Simamora, 2019; Widodo \& Najibuzzamzam, 2021). In the assessment there are principles that must be firmly held by the valuers in this case are teachers in schools. Varied forms and assessment techniques are expected to make learners to achieve maximum value, 
but in reality on the field many teachers only use monotonous forms and techniques such as multiple choices and descriptions for aspects of knowledge and practice for aspects of skills.

Then how the form and technique of assessment in the textbook of students PJOK class VIII curriculum 2013 latest to improve the learning achievement of learners (Kemendikbud RI, 2013; Simamora, 2019). Assessment in Kemendikbud (2017) is divided into three aspects, namely the assessment of attitudes, knowledge and skills. In this study, the research was only on the aspect of knowledge and skills only because the assessment on the attitude aspect of the assessment process is widely contained in the learning process, while the researched is a learning document.

\section{Research Methodology}

\subsection{Data Source}

Data source means the subject from which the data can be obtained (Arikunto, 2013; Burhaein, Tarigan, Budiana, Hendrayana, \& Phytanza, 2021). In this study, the data source is in the form of textbooks of students of PJOK class VIII curriculum 2013.

\subsection{Research Design}

This research is a type of qualitative descriptive research. This research was conducted by reviewing documents in the textbooks of students of PJOK class VIII curriculum 2013 in the form of techniques and forms of assessment on aspects of knowledge and skills.

\subsection{Instrument}

Qualitative research that becomes an instrument or research tool is the researcher itself (Burhaein, Tarigan, \& Phytanza, 2020; Sugiyono, 2015). Based on this opinion, it can be concluded that the instrument in this study is the researcher himself who has been equipped with a set of theories and data cards that contain techniques and forms of assessment of aspects of knowledge and skills. The instrument is validated by validation of content or content by experts or expert judgement in this case carried out by PJOK teaching experts.

\subsection{Data Collection Techniques}

Data collection techniques are the most important step in research, because the main purpose of research is to obtain data (Phytanza, Burhaein, Sukoco, \& Ghautama, 2018; Sugiyono, 2015). This study uses documentation recording techniques or read-note techniques. This is also supported in terms of data because it is seen from the data source obtained by researchers, namely through documents in the form of textbooks of students of PJOK class VIII curriculum 2013.

\subsection{Data Analysis}

Analytical techniques in this study use qualitative descriptive analysis techniques with data reduction steps, data presentation, conclusion / verification. This is supported from the problems that researchers examine, namely: (1) techniques and forms of assessment of aspects of knowledge in the textbooks of PJOK students in class VIII curriculum 2013 and (2) techniques and forms of assessment of aspects of skills that exist in the textbooks of students PJOK class VIII curriculum 2013. Data validity techniques are also carried out with one of them, namely Focus Group Discussion (FGD). This technique is done by exposing the procurement and description of data and 
Sports Education Study Program, University of Ma'arif Nahdlatul Ulama Kebumen

provisional results obtained in the form of analytical discussions with experts and peers (Mohamad, Sulaiman, Sern, \& Salleh, 2015).

\section{Results and Discussion}

\subsection{Resuts}

Based on the results of the engineering study and the form of textbook assessment of students of PJOK class VIII curriculum 2013 on the aspect of knowledge in get results as in Table 1.

Table 1. Study of Techniques and Forms of Assessment on Aspects of Knowledge

\begin{tabular}{|c|c|c|c|c|c|c|c|c|c|c|}
\hline \multirow[b]{2}{*}{$\begin{array}{l}\mathrm{N} \\
\mathrm{O}\end{array}$} & \multirow[b]{2}{*}{$\begin{array}{c}\text { CHA } \\
\text { PTE } \\
\text { R }\end{array}$} & \multirow[b]{2}{*}{$\begin{array}{c}\text { Materi } \\
\text { al }\end{array}$} & \multicolumn{5}{|c|}{ Assessment Techniques } & \multirow{2}{*}{$\begin{array}{l}\text { Oral } \\
\text { Q\&A }\end{array}$} & \multicolumn{2}{|c|}{ Assignment } \\
\hline & & & $\begin{array}{c}\text { Multipl } \\
\text { e } \\
\text { Choice }\end{array}$ & $\begin{array}{c}\text { Right } \\
- \\
\text { Wron } \\
\text { g }\end{array}$ & $\begin{array}{c}\text { Matchmakin } \\
\mathrm{g}\end{array}$ & $\begin{array}{l}\text { Short } \\
\text { Fill }\end{array}$ & $\begin{array}{l}\text { Descr } \\
\text { iption }\end{array}$ & & $\begin{array}{l}\text { Individ } \\
\text { ual }\end{array}$ & Group \\
\hline \multirow[t]{3}{*}{1} & $\mathrm{I}$ & SB & $*$ & - & - & - & $*$ & - & - & $*$ \\
\hline & & BV & $*$ & - & - & - & $*$ & - & - & $*$ \\
\hline & & $\mathrm{B}$ & $*$ & - & - & - & $*$ & - & - & $*$ \\
\hline \multirow[t]{3}{*}{2} & II & $\mathrm{SO}$ & $*$ & - & - & - & $*$ & - & - & $*$ \\
\hline & & BT & $*$ & - & - & - & $*$ & - & - & $*$ \\
\hline & & TM & $*$ & - & - & - & $*$ & - & - & $*$ \\
\hline \multirow[t]{3}{*}{3} & III & $\mathrm{JC}$ & $*$ & - & - & - & $*$ & - & $*$ & - \\
\hline & & LJP & $*$ & - & - & - & $*$ & - & $*$ & - \\
\hline & & $\mathrm{LJ}$ & $*$ & - & - & - & $*$ & - & $*$ & - \\
\hline 4 & IV & PS & $*$ & - & - & - & $*$ & - & - & $*$ \\
\hline 5 & $\mathrm{~V}$ & $\mathrm{KJ}$ & $*$ & - & - & - & $*$ & - & - & $*$ \\
\hline 6 & VI & SL & $*$ & - & - & - & $*$ & - & - & $*$ \\
\hline 7 & VII & AGB & $*$ & - & - & - & $*$ & - & - & $*$ \\
\hline 8 & VII & $\mathrm{AA}$ & $*$ & - & - & - & $*$ & - & - & $*$ \\
\hline 9 & IX & PB & $*$ & - & - & - & $*$ & - & - & $*$ \\
\hline $\begin{array}{l}1 \\
0\end{array}$ & $X$ & KJR & $*$ & - & - & - & $*$ & - & - & $*$ \\
\hline
\end{tabular}

Based on table 1, it can be concluded that for aspects of assessment engineering knowledge contained in the textbook of students PJOK class VIII curriculum 2013 namely multiple choice, description and assignment. Furthermore, the results of the engineering study and the form of textbook assessment of students of PJOK class VIII curriculum 2013 on aspects of skills are obtained results as in Table 2.

Table 2. Study Techniques and Form assessments on aspects of skills

\begin{tabular}{|c|c|c|c|c|c|c|}
\hline \multirow{2}{*}{ No } & \multirow{2}{*}{ Chapter } & \multirow{2}{*}{ Material } & \multicolumn{4}{|c|}{ Assessment Techniques } \\
\hline & & & Practice & Product & Project & Portfolio \\
\hline
\end{tabular}




\begin{tabular}{|c|c|c|c|c|c|c|}
\hline \multirow[t]{3}{*}{1} & I & SB & $*$ & - & - & - \\
\hline & & BV & $*$ & - & - & - \\
\hline & & B & $*$ & - & - & - \\
\hline \multirow[t]{3}{*}{2} & II & $\mathrm{SO}$ & $*$ & - & - & - \\
\hline & & BT & $*$ & - & - & - \\
\hline & & $\mathrm{TM}$ & $*$ & - & - & - \\
\hline \multirow[t]{3}{*}{3} & III & $\mathrm{JC}$ & $*$ & - & - & - \\
\hline & & LJP & $*$ & - & - & - \\
\hline & & $\mathrm{LJ}$ & $*$ & - & - & - \\
\hline 4 & IV & PS & $*$ & - & - & - \\
\hline 5 & $\mathrm{~V}$ & $\mathrm{KJ}$ & $*$ & - & - & - \\
\hline 6 & VI & SL & $*$ & - & - & - \\
\hline 7 & VII & AGB & $*$ & - & - & - \\
\hline 8 & VII & $\mathrm{AA}$ & $*$ & - & - & - \\
\hline 9 & IX & PB & - & $*$ & - & - \\
\hline 10 & $X$ & KJR & - & $*$ & - & - \\
\hline
\end{tabular}

Information: * : done, - : not done

Based on table 2, it can be concluded that for aspects of assessment technique skills contained in the textbook of students PJOK class VIII curriculum 2013 namely practice and products.

\subsection{Discussion}

Assessment in the 2013 Curriculum is divided into three aspects, namely the assessment of attitudes, knowledge, and skills (Burhaein et al., 2020; Kemendikbud, 2017; Simamora, 2019). In this study researchers limited the aspect of assessment that they wanted to research only to aspects of knowledge and skills. Researchers reviewed documents in the textbooks of PJOK students in class VIII curriculum 2013 in the form of techniques and forms of assessment on aspects of knowledge and skills. Knowledge aspect assessment technique is a process of gathering and processing information to measure the process and results of achievement of learners' competencies in the form of a combination of mastery of cognitive processes (thinking skills), remembering, understanding, applying, analyzing, evaluating, and creating with factual, conceptual, procedural, and metacognitive knowledge (Metzler, 2017; Phytanza, Burhaein, \& Pavlovic, 2021).

Assessment techniques in aspects of knowledge include writing, oral, and assignment techniques. Writing technique is a test whose questions and answers are presented in writing in the form of multiple choices, stuffing, right wrong, matchmaking, and description. Assessment with oral techniques are questions given by educators orally and learners respond to such questions orally during the learning process (Kemendikbud, 2017; Simamora, 2019). Assessment with assignment techniques is the provision of tasks to learners to measure or facilitate learners to acquire or improve their knowledge. Based on the results of the study conducted by researchers, in 
the textbook of students Indonesian Class VIII Curriculum 2013 there are several examples of techniques used to measure students' abilities on aspects of knowledge. Here are the knowledge aspect assessment techniques with some examples found in students' textbooks Indonesian Class VIII Curriculum 2013.

\section{A. Multiple Choice Write Test}

Written tests or often known by the term paper and pencil test is a test that demands answers from learners in written form. In this written test there are 5 forms of assessment contained in the textbook assessment of students of PJOK class VIII curriculum 2013.

\section{1) Multiple Choice}

Assessment technique in the form of multiple choices consists of the subject carrier and the choice of answers. Multiple choice assessment techniques are found in chapters I, II, III, IV, V, VI, VII, VIII, IX and X. This assessment technique is highly in PJOK subjects due to its effectiveness and effectiveness. Multiple choice techniques tend to present a choice of answers with one correct answer and another wrong choice making it easier to provide value. This is in line with what Arifin (2012) says that multiple-choice forms can be used to measure more complex learning outcomes and with regard to aspects of memory, understanding, application, analysis, synthesis, and evaluation. The test question in the form of multiple choice consists of the subject matter and the choice of answers that have been provided. The subject matter can be raised in the form of questions and can also be in the form of rudimentary statements that are often called stems, while the choice of answers can be answered.

\section{2) Right Wrong}

A true test is a form of test that consists of a statement that has two possibilities, namely right or wrong (Arikunto, 2013). This kind of assessment technique is not used in the textbooks of students of PJOK class VIII curriculum 2013 because it is considered less suitable for the assessment process so that it is not present in chapters I, II, III, IV, V, VI, VII, VIII, IX and X. This assessment technique students provided questions with the option of answering right or wrong. The disadvantage of this form of test is that children are required to memorize the material instead of understanding it with the answers that have been provided, namely right or wrong. But this form of assessment makes it easier for teachers to provide value unlike the form of assessment of description that requires the teacher to understand the intent of the child's answer. With the advantages and disadvantages of this form of test, educators should expect to use this form of test for assessment variations, so that students are not saturated with that form of test.

\section{3) Matchmaking}

This assessment technique requires learners to match, match, adjust, or connect between the two statements provided (Burhaein, Demirci, Lourenço, Németh, \& Phytanza, 2021; Kemendikbud, 2017). This kind of assessment technique is not used in the textbooks of students of PJOK class VIII curriculum 2013 in chapters I, II, III, IV, V, VI, VII, VIII, IX and X. This form of assessment makes it easy for teachers to provide grades, but with the answers that have been provided, this will reduce children's creativity in thinking. Learners are only asked to match a statement with the choice of answers that have been provided by the teacher, but occasionally educators need to use this form of test. With the monotony of the use of forms of assessment using multiple choices, descriptions and assignments, this form of test can be used to alternative in assessment on aspects of knowledge.

\section{4) Short FIll}

A short fill test completes or perfects a form of objective test consisting of statements that are deliberately omitted in part, or that are intentionally made incomplete (Phytanza \& Burhaein, 2019; Simamora, 2019). This kind of assessment technique is not used in the textbooks of students PJOK class VIII curriculum 2013 in chapters I, II, III, IV, V, VI, VII, VIII, IX and X. This 
assessment requires learners to find their own answers without being provided by the teacher. The teacher presents a question that asks to fill a problem with the right statement.

\section{5) Description}

A description test or essay is a form of question that demands the answer of learners in the form of a description using its own language (Kemendikbud, 2017; Pramantik \& Burhaein, 2019). This assessment technique is contained in chapters I, II, III, IV, V, VI, VII, VIII, IX and X. This form of test actually hones the creativity of children's thinking because learners are asked to convey answers in their own language style without being provided with a choice of answers such as multiple choices. The disadvantage of this kind of assessment technique is that with different styles of children's language, teachers are required to be able to understand the maxims of the learners' answers. This is different from multiple choice scoring techniques, right wrong or matchmaking.

\section{B. Oral}

Oral tests are questions given by educators orally and learners respond to these questions orally during the learning process. This kind of assessment technique is not used in the textbooks of students of PJOK class VIII curriculum 2013 in chapters I, II, III, IV, V, VI, VII, VIII, IX and X. This form of assessment is still commonly used by teachers, especially PJOK subjects because teachers are required to provide in advance the sheets / instruments of questions that will be asked to students.

\section{Assignment}

Assignment is the provision of tasks to learners to measure or facilitate learners acquiring or increasing knowledge. This kind of assessment technique is used in the textbooks of students of PJOK class VIII curriculum 2013 in chapters I, II, III, IV, V, VI, VII, VIII, IX and X. the form varies there are individual, but there are also those that are grouped even some are done in school or done outside of school.

Tthe assessment in the 2013 Curriculum is divided into three aspects, namely the assessment of attitudes, knowledge, and skills. Skills assessment techniques there are 4 types of assessment techniques (Kemendikbud, 2017; Simamora, 2019).

\section{1) Practice}

Practice assessment is an assessment that requires a response in the form of skills to perform an activity in the same way as the demands of competence. Assessment techniques using practice are found in chapters I, II, III, IV, V, VI, VII and VIII. This assessment is most often used in PJOK subjects because much practice is needed in the learning process. The forms of tasks in this assessment better reflect the abilities required in practices such as soccer, volleyball, basketball in others. Practice assessment becomes the choice of PJOK teachers in assessing the child's skill field. By looking at the performance of children in making movements, teachers will provide value with instruments that have been made before.

\section{2) Product}

As stated in the Kemendikbud (2017) product assessment is an assessment of the skills of learners in applying the knowledge possessed into the form of the product in a certain time in accordance with the criteria that have been set both in terms of process and final results. The technique of assessment using practice is contained in chapter IX (material on promiscuity) and X (material about road safety) alone because of its more theoretical orientation. This assessment aims to assess the skills of learners in making certain products in connection with the achievement of learning goals in the classroom to develop ideas in designing and demonstrating innovation and 
creation can be power points such as those contained in chapter IX (material on promiscuity) and X (material about road safety).

\section{3) Project}

Project assessment is an activity to determine the ability of students to apply their knowledge through the completion of a particular instrument. Project assessment starts from collection activities, organizing, assessment, to presentation of data. The assessment of the project will provide information about the understanding and knowledge of learners in the learning process. This assessment can measure the ability of learners in applying the knowledge and ability of learners to communicate information that has been learned or obtained. Project assessment techniques are not contained in the textbooks of Class VIII students of the 2013 curriculum starting from chapters I, II, III, IV, V, VI, VII, VIII, IX and X.

\section{4) Portfolio}

Portfolio assessment is an ongoing assessment based on a collection of reflective integrative information that demonstrates the development of learners' abilities in a given period. The purpose of this assessment is to determine the results of the work and the process of how the work is obtained as one of the evidence that can show the achievement of learning learners, namely achieving basic competencies and indicators that have been established. In addition to serving as a storage place for the work of learners, the portfolio can also be used to find out the development of learners' competencies. Portfolio assessment techniques are not contained in students' textbook Class VIII curriculum 2013 starting from I, II, III, IV, V, VI, VII, VIII, IX and X.

\section{Conclusion}

Based on the results of qualitative descriptive analysis and discussion of the results of research analysis can be concluded that the technique of assessing aspects of knowledge in the textbook of students PJOK class VIII curriculum 2013 used is multiple choice, description and assignment. For the technique of reading, correctly wrong, matchmaking and Q\&A has not been used in the textbook assessment of students PJOK class VIII curriculum 2013. Skills aspect assessment techniques in the textbooks of PJOK students in class VIII of the 2013 curriculum used are practices and products. For project and portfolio assessment techniques have not been used in the textbook assessment of PJOK class VIII students curriculum 2013. This research contributes to the importance of subsequent research on the development of variation in forms and complete assessment techniques including aspects of attitudes in PJOK.

\section{References}

Arifin. (2012). Evaluasi Pembelajaran Prinsip, Teknik, dan Prosedur. Bandung: Remaja Rosdakarya.

Arikunto, S. (2013). Prosedur Penelitian Suatu Pendekatan Praktik. Jakarta: Asdi Mahasatya.

Azizah, A. R., \& Sudarto, E. P. (2021). Minat Mengikuti Ekstrakurikuler Bola Voli Siswa Smp Negeri 3 Satu Atap Karangsambung Kecamatan Karangsambung Tahun Ajaran 2019/2020. JUMORA: Jurnal Moderasi Olahraga, 1(01), 35-44. https://doi.org/10.53863/mor.v1i01.132

Burhaein, E. (2017). Aktivitas Fisik Olahraga untuk Pertumbuhan dan Perkembangan Siswa SD. Indonesian Journal of Primary Education, 1(1), 51-58. https://doi.org/10.17509/ijpe.v1i1.7497 
Burhaein, E. (2020). Bagaimana Pendidikan Jasmani Adaptif di Era New Normal. In Bunga Rampai Strategi, Proses, Evaluasi, dan Model Pembelajaran Pendidikan Jasmani, Olahraga, dan Kesehatan (PJOK) pada Era Pandemi Covid-19. Surabaya: UNESA University Press.

Burhaein, E., Demirci, N., Lourenço, C. C. V., Németh, Z., \& Phytanza, D. T. P. (2021). Coping with the COVID-19 pandemic: the role of physical activity. An international position statement. International Sports Studies, 43(1), 52-70. https://doi.org/10.30819/iss.43-1.05

Burhaein, E., Tarigan, B., Budiana, D., Hendrayana, Y., \& Phytanza, D. T. P. (2021). Physical Activity Level of Students with Disabilities during COVID-19 Pandemic. Jurnal Pendidikan Jasmani Dan Olahraga, 6(2), 19-21. https://doi.org/10.17509/jpjo.v6i2.38547

Burhaein, E., Tarigan, B., \& Phytanza, D. T. P. (2020). The experience and understanding of the K13 curriculum implementation of Indonesian teachers of Adapted Physical Education (APE). International Sports Studies, 42(e), 29-42. https://doi.org/10.30819/iss.42-e.04

Irawan, Y. F., \& Limanto, D. (2021). Pengaruh Kecerdasan Emosi dan Kesiapan Diri Terhadap Pertandingan Pada Pemain Walet Muda Futsal Academy Kebumen Tahun 2020. JUMORA: Jurnal Moderasi Olahraga, 1(01), 18-26. https://doi.org/10.53863/mor.v1i01.130

Kemendikbud. (2017). Panduan Penilaian oleh Pendidik dan Satuan Pendidikan untuk Sekolah Menengah Pertama. Jakarta: Kementerian Pendidikan dan Kebudayaan.

Kemendikbud RI. (2013). Dokumen kurikulum 2013.

Kemendikbud RI. (2016). Konsep Dasar Penguatan Pendidikan Karakter. Jakarta: Kementerian Pendidikan dan Kebudayaan.

Metzler, M. W. (2017). Instructional models in physical education (3rd Ed). https://doi.org/https://doi.org/10.4324/9781315213521

Mohamad, M. M., Sulaiman, N. L., Sern, L. C., \& Salleh, K. M. (2015). Measuring the Validity and Reliability of Research Instruments. Procedia - Social and Behavioral Sciences, 204(November 2014), 164-171. https://doi.org/10.1016/j.sbspro.2015.08.129

Mumpuni, A. (2018). Integrasi Nilai Karakter dalam Buku Pelajaran. Yogyakarta: CV Budi Utama.

Phytanza, D. T. P., \& Burhaein, E. (2019). Aquatic activities as play therapy children autism spectrum disorder. International Journal of Disabilities Sports and Health Sciences, 2(2), 64 71. https://doi.org/10.33438/ijdshs.652086

Phytanza, D. T. P., Burhaein, E., \& Pavlovic, R. (2021). Gross Motor Skills Levels in Children with Autism Spectrum Disorder during the COVID-19 Pandemic. International Journal of Human Movement and Sports Sciences, 9(4), 738-745. https://doi.org/10.13189/saj.2021.090418

Phytanza, D. T. P., Burhaein, E., Sukoco, S., \& Ghautama, S. W. (2018). Life Skill Dimension based on Unified Sports Soccer Program in Physical Education of Intellectual Disability. Yaşam Becerileri Psikoloji Dergisi, 2(4), 199-205. https://doi.org/https://doi.org/10.31461/ybpd.453865

Pramantik, I. A. D., \& Burhaein, E. (2019). A Floor Time Approach to Improve Learning Outcomes of the Body Roll to the Side in Adaptive Physical Education Learning : Classroom Action Research Study on Two Cerebral Palsy Students. International Journal of Disabilities Sports and Health Sciences, 2(2), 45-53. https://doi.org/10.33438/ijdshs.652061

Simamora, B. S. (2019). Buku Guru Aktif Berolahraga Pendidikan Jasmani, Olahraga, dan Kesehatan: SD/MI Kelas V. Jakarta: Kementerian Pendidikan dan Kebudayaan.

Sugiyono. (2015). Metode Penelitian Pendidikan Pendekatan Kuatitatif, Kualitatif, dan R\&D. 
Bandung: Alfabeta.

Sutopo, W. G., \& Misno. (2021). Analisis Kecepatan Tendangan Sabit Pada Pesilat Remaja Perguruan Pencak Silat Tri Guna Sakti Di Kabupaten Kebumen Tahun 2020. JUMORA: Jurnal Moderasi Olahraga, 1(01), 27-34. https://doi.org/10.53863/mor.v1i01.131

Widiyono, I. P., \& Mudiono. (2021). Keterampilan Dasar Futsal Peserta Ektrakurikuler di SMK Ma'arif 1 Kebumen Tahun Ajaran 2019/2020. JUMORA: Jurnal Moderasi Olahraga, 1(01), 10-17. https://doi.org/10.53863/mor.v1i01.129

Widodo, P., \& Najibuzzamzam, A. (2021). Perbandingan Model Pembelajaran Daring Dan Tatap Muka Penjaskes Mts Darussa'adah Pada Masa Pandemi Tahun Ajaran 2019/2020. JUMORA: Jurnal Moderasi Olahraga, 1(01), 1-9. https://doi.org/10.53863/mor.v1i01.128 